\title{
THE IMPACT OF WORKAHOLISM ON CONSUMER FOOD WASTE
}

\author{
Ramona Elena Cantaragiu ${ }^{1 *}$ and Valentina Mihaela Ghinea ${ }^{2}$ \\ ${ }^{1), 2)}$ University of Economic Studies, Bucharest, Romania
}

\author{
Please cite this article as: \\ Cantaragiu, R.E. and Ghinea, V.M., 2020. The Impact \\ of Workaholism on Consumer Food Waste. Amfiteatru \\ Economic, 22(Special Issue No. 14), pp. 1140-1158.
}

\section{Article History}

Received: 30 June 2020

Revised: 12 August 2020

Accepted: 18 September 2020

DOI: $10.24818 / \mathrm{EA} / 2020 / \mathrm{S} 14 / 1140$

\begin{abstract}
The present study explores the influence of workaholism on consumer food waste using an extended version of the theory of planned behaviour and the BWAS workaholism scale. The study is quantitative in nature and data collection was done through a web-based survey filled in by 194 Romanian employees recruited through convenience sampling. Data analysis was performed using IBM SPSS and the results showed that the influence of workaholism on consumer food waste is multifaceted. Workaholism has no influence on the predictors of intention to reduce food waste such as food waste attitudes, perceived behavioural control, with the exception of subjective norms, which are predicted by only one facet of workaholism (i.e., problems). However, workaholism has a small influence on food waste behaviours (e.g., food reusing, food storage etc.) and particularly on the estimated amount of food wasted. The two most salient facets of workaholism were conflict and problems and the analysis revealed that problematic workaholics (high conflict, high problems) tend to waste more food than functional workaholics (high conflict, low problems). Overall, the study proves the need to further explore the connections between different types of workaholism and consumer food waste.
\end{abstract}

Keywords: workaholism, consumer food waste, food waste attitudes, food waste behaviours

JEL Classification: J22, D12

\footnotetext{
* Correspondent author, Ramona Elena Cantaragiu - e-mail: ramona_cantaragiu@yahoo.com
} 


\section{Introduction}

In the context of an increasing complexity of the labour market, which encourages viewing the workplace not only as a source of income, but also as a form of social integration and positioning of individuals within the family, social or cultural group (Castillo and Gomez, 2012), workaholism is shaping itself to be a phenomenon not only complex but also ambiguous. According to Andreassen (2014), the workplace is a provider of income, but also works to strengthen the employees' sense of identity, giving them a sense of purpose and helping them relate to and integrate into society. Although the vocabulary used in companies abounds in terms such as high work investment, work beyond expectations, etc., which contribute to shaping a certain organizational culture designed to motivate the employee and lead him without thinking to long working hours and all-consuming obsession with work (Ng, Sorensen and Feldman, 2007; Griffiths, 2011), workaholism thus encouraged is suspected to have some of the most contradictory effects (psychological, physical and social), both for the person concerned and those close to him, as well as for his work environment. That is why the extensive research over the last decades analysed this phenomenon not only in relation to well-being, but also in correlation with physical health and work-life balance. Moreover, instruments for the identification and measurement of workaholism have also been developed and used in a host of studies aimed at exploring the impact of workaholism on different facets of personal and professional life.

However, although the scientific world agrees with the idea of the impact of workaholism on different life aspects, to date, empirical research in areas that go beyond mere impacts on health and work-related outcomes remains weak. In particular, the impact of workaholism on consumption habits and attitudes related to consumerism, waste and recycling has not been thoroughly investigated. This is an interesting research gap considering that there has been a rise in the interest of studying the predictors of food waste at the consumer level and there are certain studies which have related workaholism to overconsumption, at least in theory if not based on actual empirical findings (Maccheroni, Marinacci and Rustichini, 2014; Ilyn, 2015). The literature on consumer food waste behaviours has explored a host of different factors (i.e., attitudes, perceptions, moral norms, emotions, socio-demographic characteristics, situational configurations etc.) usually under the theory of planned behaviour (Graham-Rowe, Jessop and Sparks, 2015; Mondejar-Jimenez, et al., 2016; Russell, et al., 2017; Soorani and Ahmadvand, 2019; Mak, Yu and Tsang, 2020), but most of the models have a somewhat mediocre explanatory power (i.e., less than $60 \%$ ). This indicates that there is a need to move beyond the factors traditionally considered as predictors of consumer food waste. The investigation of the impact of workaholism on the food waste related behaviours at the household level which is performed in the present study aims to address this gap and to create a bridge between workaholism and food waste literature which would provide further fruitful avenues for study. The study is divided into four parts: the first part contains a succinct presentation of the literature on workaholism, the second part details the research methodology, the third part lays out the main results regarding the ways in which workaholism influences the intention to avoid food waste as well as the behaviours associated to food waste, while the last part presents the conclusions of the study.

\section{Literature review}

Being considered highly motivated and dedicated individuals, ready to work hard when necessary, workaholics (also called reliable workhorses by Ishiyama and Kitayama, 1994) 
are the dream of any organization and, consequently, the central point of most recruitment processes. Due to their willingness to expend additional efforts without hesitation, their characteristic features are often, if not explicitly, depicted in recruitment announcements or even in job descriptions and specifications. On the other hand, given that collective thinking is rooted in the belief that business success and well-being go hand in hand with discretionary and sometimes limitless work (Hewitt and Luce, 2006), overtime has come to function, at the same time, as a subject of praise and dissatisfaction, but also as the foundation of the hope for a fulminant professional ascent. Thus, in everyday life, work dependence, workaholism and overwork are synonymous terms, considered to refer, in general, to more than 50 hours worked per week (Mosier, 1983; Andreassen, 2013) or to people who invest more time and energy in the tasks assigned to the workplace than required (Machlowitz, 1980).

Although over time, several definitions of the concept of workaholism have been formulated and circulated, most start from the idea of addiction found in the term (alcoholism), and end up referring to excessive work (as a behavioural component) and compulsive work (cognitive component) (Porter, 1996; Schaufeli and Taris, 2004), workaholism being seen as a combination of these two components. If overwork is represented by (objective) indicators of working time (such as the number of hours worked, work at the expense of free time and the degree of distraction from other activities), compulsive work brings into question personality factors such as perfectionism, the consciousness of the individual, his stubbornness and rigidity, order, desire for domination and obsessive thinking (Robinson, 1996).

Whether it is explained as a subjective experience caused by an uncontrollable and compulsive need to work incessantly, leading to loss of control for the benefit of work dependence (Oates, 1971; Machlowitz, 1980), or as voluntary spending of time in workrelated activities, with negative consequences on social and family aspects (Spence and Robbins, 1992), workaholism is generally perceived as an attitude, behavioural or personality trait, obsession and/or addiction. Viewed from the perspective of addiction, workaholism is described as excessive concern for work, determined by an uncontrollable motivation and accompanied by an excessive level of effort and energy that affects private relationships, leisure and/or health (Sussman, 2012; Andreassen, 2013). Viewed from the perspective of behavioural tendency, although quite stable, it is likely to be enhanced by circumstantial factors and last, but not least, by certain aspects/dimensions of technological advancement (Internet, smartphone, laptop, etc.). Often the workaholic continues work, despite the obvious negative effects.

While researchers such as Porter (2004) and Schaufeli, Taris and van Rhenen (2008) sustain the influence of situational factors and their triggering power (such as acute financial need, aspects of organizational culture, or even marital issues), Snir and Harpaz (2012) differentiate between workaholism and overwork determined by necessity, whether it is internal situational factors (adjacent to the employee) such as acute need for money or external (characteristics of the organization or its external environment) such as peak periods with huge requests/orders. Snir and Harpaz (2012) also consider that those who work out of devotion, those who take refuge in work out of a desire to avoid intimate relationships, as well as those who are simply not interested or do not feel the need for recreational activities should not be included in the category of workaholics. In the same vein, Mudrack and Naughton (2001) consider that, in order to be classified as a workaholic, it is not enough for an employee to spend a very large number of hours working, especially if this is imposed by the organization or is simply necessary for the performance of the duties required by the position. 
Thus, a fundamental element of the manifestation of workaholism is outlined: internal causality (internal, personal, subjective needs and motivations). On this perspective, Porter (1996) previously agreed by supporting the prevalence of internal reasons for maintaining a certain behaviour, and Clark et al. (2010) also highlighted certain personality traits (e.g., narcissism, affectivity/emotions, whether positive or negative, perfectionism) that predispose the individual and facilitate the manifestation of workaholism. By noting the importance of work, as a process, and its outcome, when they provide rewards and gratifications that are most likely to increase self-esteem (the superior levels of Maslow's Pyramid), in 2004, Porter linked workaholism to self-esteem.

Throughout time, several categorizations of workaholics have been proposed. Scott, Moore, and Miceli (1997) distinguished between compulsively addicted, perfectionist, and achievement-oriented workaholics. In parallel, Spence and Robbins (1992) and later Bonebright et al. (2000) distinguished between enthusiastic workaholics whose work brings them joy and contentment, and whose activity is characterized by a considerable level of engagement determined by an uncontrollable internal need to work, and non-enthusiastic workaholics, who, although engaged and intrinsically motivated as well, seem not to be satisfied or to enjoy the work done in excess. In the same vein, the correlation between the level of job engagement and workaholism is considered important and necessary to be deepened by Taris, Schaufeli and Shimazu (2010), and therefore van Beek, Taris \& Schaufeli (2011) even proposed a possible classification into workaholics, engaged workaholics and engaged employees. As a result of their research, $\mathrm{Ng}$ et al. (2007) concluded that all workaholics feel gratified and satisfied with the work itself, as long as it manages to neutralize their uncomfortable emotions and moods (anxiety, guilt, etc.) experienced when not working. In 2013, Robinson identified four other different categories of workaholics: a) bulimic, which alternates between the perfect accomplishment of the task and its nonfulfilment at all; b) the relentless, focused on the pace of work and obsessed with completing tasks quickly, respecting deadlines no matter what. It is practically extremely difficult for him to stop working; c) the savouring, who pays disproportionate and unjustified attention to detail; and d) the one with attention-deficit, who starts more projects at the same time, but gets bored quickly, becomes restless and therefore constantly looks for new challenges.

The first methods of identifying and measuring workaholism were recorded in the 1980s. Thus, starting from the premise that workaholism is a type A behaviour rather than an addiction, Robinson developed in 1989 the Work Addiction Risk Test (WART) (Patel, et al., 2012). Complementarily, in 1992, considering workaholism an obsessive-compulsive attitude and differentiating between enthusiastic and non-enthusiastic workaholics (the latter also called real workaholics), Spence and Robbins developed the Workaholism Battery (WorkBAT) (Patel, et al., 2012). Subsequently, starting from the premise that work dependence is accompanied by the existence of an irresistible inner force that leads to hard work in the form of excessive and compulsive activity, and substantiating their research on both WART and WorkBAT scale, Schaufeli et al. (2009) developed The Dutch Work Addiction Scale (DUWAS), actually adapting the already existing tests to their use in the Dutch culture (Taris, Schaufeli and Verhoeven, 2005). Other less commonly used tests include: Schedule for Nonadaptive and Adaptive Personality - Workaholism, SNAP-Work, which considers workaholism a personality disorder, and is based on trait theory and clinical psychopathology (Clark, 1993) and Non-Required Work Scale and Control of Others Scale developed by Mudrack and Naughton (2001) and which evaluates workaholism in terms of observable behavioural tendencies. More recently, considering the components of 
behavioural dependence highlighted by Brown (1993), as well as the model of Griffiths (2005), Andreassen et al. (2012) developed the Bergen Work Addiction Scale (BWAS). The brief review of the literature proves that there is no consensus regarding the definition of workaholism and, implicitly, its measurement and delimitation between pathological and normal states, this due also to the absence of a significant number of studies developed on representative samples (Andreassen, 2014).

Although studies have concluded that workaholism is more common among managerial staff and mainly in certain sectors of activity such as agriculture, construction, consulting, trade and communication (Andreassen, et al., 2012; Taris, et al., 2012), when it comes to the effects of its manifestation, most researchers recognize the negative aspects that affect both the individual and his family and also the organization in which he operates: conflicts regarding the private-professional life, impaired health, strain, burnout, decreased performance, lack of satisfaction (Oates, 1971; Bonebright, et al., 2000; Schaufeli, Shimazu and Taris, 2009; Griffiths, 2011; Andreassen, et al., 2012; Robinson, 2013). There are also studies that highlight the appearance of sleep problems, the manifestation of fatigue at work and difficulties in waking up in the morning (Kubota, et al., 2010), or insomnia, stress and exhaustion (Andreassen, Ursin and Eriksen, 2007). Labour-family conflicts are frequently attested outside the workplace, the individuals failing to function similarly to nonworkaholics (Bonebright, et al., 2000). Thus, although the general public traditionally believes that workaholics have at least a stable, if not thriving, financial situation (Harpaz and Snir, 2003), as well as more satisfaction (Peiperl and Jones, 2001), it was proven that, on the contrary, workaholics have a precarious psychological situation, a low perceived level of health and happiness and a diminished level of performance at work (Chamberlin and Zhang, 2009). "Seven-eleven" spouses (7AM-11PM) are at work all day, from early in the morning until late in the evening, not spending time with their family members or friends (Ishiyama and Kitayama, 1994).

The main aim of the present study is to examine the impact of workaholism on food waste at the consumer level through the lens of the theory of planned behaviour. The theory of planned behaviour has been used extensively in past studies in order to explore the different determinants of consumer food waste and the findings have shown that there is a host of different categories of factors which have a direct impact either on the intention to reduce food waste or on food waste behaviours. In particular, it has been consistently proven that food waste at the consumer level is influenced by attitudinal factors such as personal beliefs about the negative consequences of food waste on personal finance, social inequality, environmental issues which are usually associated with feelings of guilt of regret that result from wasting food (Russell, et al., 2017; Soorani and Ahmadvand, 2019). Moreover, previous studies have shown that consumer food waste is influenced by perceptions of behavioural control and the knowledge related to food labelling, storing, preparation etc. (Mak, et al., 2020). Workaholism usually results in low self-esteem (Porter, 1994) which can reduce perceived behavioural control in several fields, including the management of food waste, and thus, it can be presumed that higher levels of workaholism are associated with lower perceived behavioural control of food waste. Food waste generated by households also has a direct connection with the type of roles that individuals think they should play inside the household, especially the good provider role which implies that the individual has to ensure that all members of the household are properly fed (Visschers, et al., 2016). Since workaholism is usually associated with a low work-life balance and household conflicts (Andreassen, et al., 2013), it could be possible for workaholics to buy more food in order to 
show that they care for their families even if they do not spend sufficient time with them. Finally, studies have also linked food waste at the consumer level with several situational factors such as the frequency of eating out, the time available for shopping and cooking, the availability of infrastructure for recycling etc. (Mondejar-Jimenez, et al., 2016). Since workaholism is associated with long working hours, it is possible that workaholism reduces home cooking and increases take away or eating out which is usually linked to increases in food waste.

The conceptual framework used in the present study is showcased in figure no. 1.

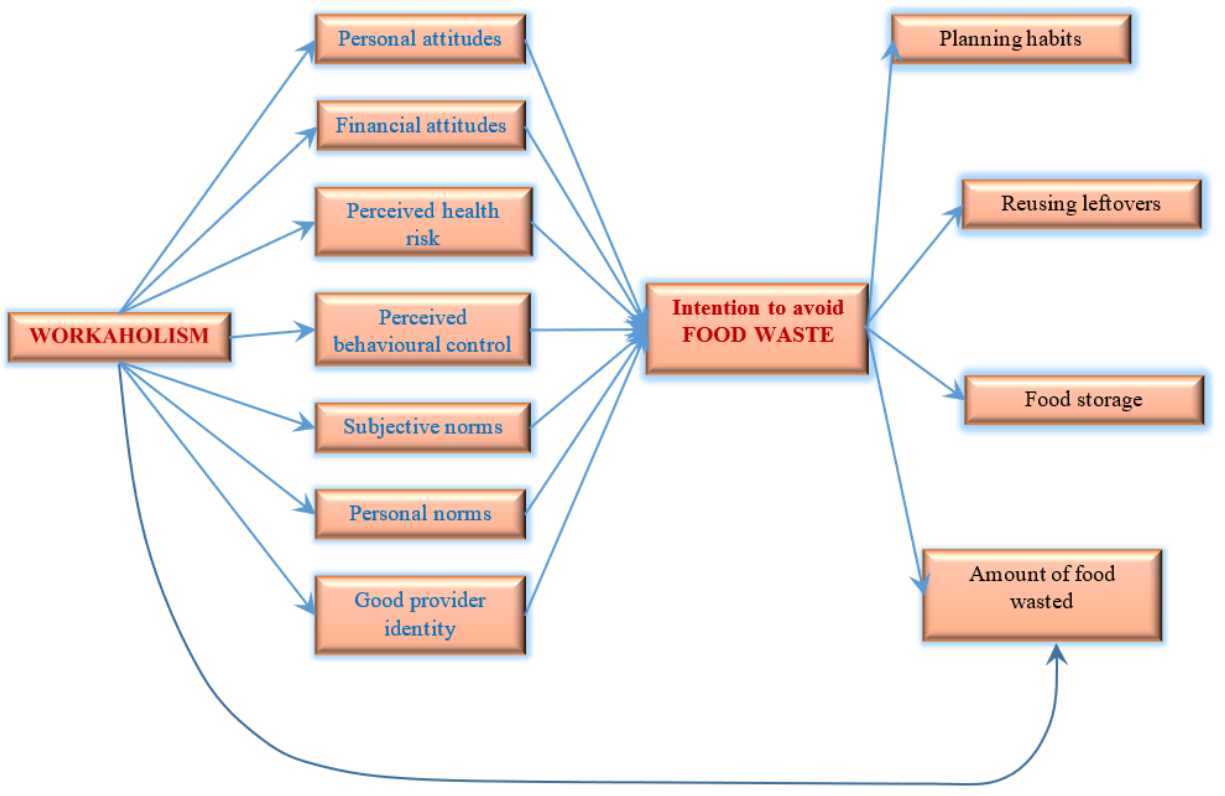

Figure no. 1. Conceptual framework

\section{Research methodology}

The present study has an exploratory nature since it aims to explore the impact of workaholism on food waste at the consumer level. Based on the review of the literature review presented previously the following hypotheses were developed:

- H1: The intention to avoid food waste is predicted by personal attitudes, financial attitudes, perceived health risk, perceived behavioural control, subjective norms, personal norms, and good provider identity.

- H2: Workaholism influences the predictors of intention to avoid food waste.

- H3: The intention to avoid food waste and workaholism determine the behaviours associated to food waste (i.e., amount of food waste, food storage, planning habits, and reusing leftovers).

Data was collected using a web-based survey created with Google Forms. The participants were recruited using convenience sampling. The invitation to participate in the study was 
posted on several social media platforms (i.e., WhatsApp, Facebook) and sent through email to the contacts of the authors. Participants were informed about the purpose of the study and their rights (i.e., the right to refuse participation, the right to personal identity protection etc.). To be included in the sample participants had to be over 18 , be employed, and to reside in Romania. Data was collected in the month of June 2020. Data analysis was performed using IBM SPSS.

The survey included three main sections as follows:

Workaholism: For the measurement of workaholism we adapted the scale introduced by Andreassen et al. (2012) which includes seven items, each measured on a 5-point Likert scale ( 1 - never, 5 - always). The scale includes an item for each aspect of workaholism (i.e., salience, tolerance, mood modification, relapse, withdrawal, conflict, and problems) and has been shown to be unidimensional. The scale was chosen due to its shortness and close correlation with other popular workaholism scales such as WORKBAT and WART. According to Andreassen et al. (2012), for a participant to be consider as displaying a high level of workaholism, it is necessary to have responses of 4 or more to at least 4 out of the 7 items.

Food waste attitudes and behaviours: For the application of TPB on food waste at the consumer level, we included the following predictors of food waste avoidance intentions from Visschers et al. (2016), each measured using a single item measured on a 5-point Likert scale (1-never, 5-always). In total, there were seven items for 7 predictors of food waste avoidance intentions (i.e., personal attitudes, financial attitudes, perceived health risk, subjective norms, personal norms, good provider identity). The intention to avoid food waste was measured using a single item (I try to produce only very little food waste.), while food waste behaviours were measured using four different items related to planning habits, reusing leftovers, food storage and the estimated amount of household food waste. For the estimated amount of food waste, participants were asked to choose between five options, i.e., below $20 \%$, between $20 \%$ and $40 \%$, between $40 \%$ and $60 \%$, between $60 \%$ and $80 \%$, and above $80 \%$. The descriptive statistics for the items related to food waste attitudes and behaviours are presented in table no. 3 .

Socio-demographic information: Participants were asked to state their age, gender (coded with 1 for females and 2 for males), education (coded from 1 to 4 ), the average number of hours worked per day, the average monthly household income (coded from 1 to 4 ) and the size of their household.

\section{Research results}

\subsection{Descriptive statistics}

In total, 194 responses were valid. The ages of the participants ranged from 18 to 56 $(\mathrm{M}=32.75 ; \mathrm{SD}=10.17)$. The majority of the sample were female $(74.7 \%)$, university educated $(88.1 \%)$, living with at most 3 other people in the household $(71.7 \%)$ and with an average household income below $6000 \mathrm{RON}$ (57.7\%). The number of hours worked per day ranged from 2 to $17(\mathrm{M}=8.25 ; \mathrm{SD}=2.41)$. The details regarding the socio-demographic characteristics of the participants are presented in table no. 1. 
Table no. 1. Socio-demographic characteristics

\begin{tabular}{|l|l|c|}
\hline \multirow{3}{*}{ Gender } & Male & $74.7 \%$ \\
\cline { 2 - 3 } Education & Female & $25.3 \%$ \\
\hline \multirow{5}{*}{$\begin{array}{l}\text { Average monthly } \\
\text { household income }\end{array}$} & High school degree & $11.9 \%$ \\
\cline { 2 - 3 } & Bachelor degree & $49.0 \%$ \\
\cline { 2 - 3 } & Master's degree & $32.5 \%$ \\
\cline { 2 - 3 } & PhD & $\begin{array}{l}\text { Between 3000 RON and 6000 RON } \\
\text { (including 6000 RON) }\end{array}$ \\
\cline { 2 - 3 } & $\begin{array}{l}\text { Between 6000 RON and 9000 RON } \\
\text { (including 9000 RON) }\end{array}$ & $14.9 \%$ \\
\cline { 2 - 3 } & Above 9000 RON & $24.8 \%$ \\
\hline \multirow{5}{*}{ Household size } & 1 & $24.2 \%$ \\
\cline { 2 - 3 } & 2 & $18.0 \%$ \\
\cline { 2 - 3 } & 3 & $28.5 \%$ \\
\cline { 2 - 3 } & 4 & $20.6 \%$ \\
\cline { 2 - 3 } & 5 or more & $7.7 \%$ \\
\hline
\end{tabular}

The descriptive statistics for the items used to measure workaholism are presented in table no. 2. Based on this scoring system, $68.6 \%$ of the sample displayed a low level of workaholism (coded with 1), while $31.4 \%$ displayed a high level of workaholism (coded with 2). The scale showed an acceptable level of internal reliability, with a Cronbach's alpha of 0.734.

Table no. 2. Descriptive statistics for the workaholism scale items

\begin{tabular}{|l|c|c|}
\hline Item & M & SD \\
\hline Salience - Thought I could free more time to work & 3.05 & 1.012 \\
\hline Tolerance - Spent much more time working than initially intended & 3.52 & .917 \\
\hline $\begin{array}{l}\text { Mood modification - Worked in order to reduce feelings of guilt, } \\
\text { anxiety, helplessness and depression }\end{array}$ & 2.58 & 1.141 \\
\hline $\begin{array}{l}\text { Relapse - Been told by others to cut down work without listening to } \\
\text { them }\end{array}$ & 3.02 & 1.154 \\
\hline $\begin{array}{l}\text { Withdrawal - Become stressed if I have been prohibited from } \\
\text { working }\end{array}$ & 2.73 & 1.069 \\
\hline $\begin{array}{l}\text { Conflict - Deprioritized hobbies, leisure activities and exercise } \\
\text { because of work }\end{array}$ & 3.30 & 1.193 \\
\hline $\begin{array}{l}\text { Problems - Worked so much that it has negatively influence my } \\
\text { health }\end{array}$ & 2.66 & 1.071 \\
\hline
\end{tabular}

Notes: $\mathrm{M}$ - mean, $\mathrm{SD}$ - standard deviation.

The descriptive statistics for the items used to measure the behaviours associated to food waste are presented in table no. 3 . 
Table no. 3. Descriptive statistics for food waste attitudes and behaviours

\begin{tabular}{|l|c|c|}
\hline Item & M & SD \\
\hline $\begin{array}{l}\text { Intention to avoid food waste - I try to produce only very little food } \\
\text { waste. }\end{array}$ & 3.93 & .987 \\
\hline $\begin{array}{l}\text { Personal attitudes - It upsets me when unused products end up in the } \\
\text { when unused products end up in the waste bin. }\end{array}$ & 4.16 & .971 \\
\hline Financial attitudes - I think that wasting food is a waste of money. & 3.91 & 1.078 \\
\hline $\begin{array}{l}\text { Perceived health risk - I think that consuming food products expired } \\
\text { a few days ago does not pose health risks. }\end{array}$ & 2.40 & 1.317 \\
\hline $\begin{array}{l}\text { Perceived behavioural control - I have the feeling that I cannot do } \\
\text { anything about the food wasted in my household. }\end{array}$ & 2.24 & .914 \\
\hline $\begin{array}{l}\text { Subjective norms - People who are important to me find my attempts } \\
\text { to reduce food waste unnecessary. }\end{array}$ & 2.15 & .969 \\
\hline $\begin{array}{l}\text { Personal norms - I have been raised to believe that food should not } \\
\text { be wasted, and I still live according to this principle. }\end{array}$ & 3.83 & 1.021 \\
\hline $\begin{array}{l}\text { Good provider identity - I tend to buy more food than necessary to } \\
\text { ensure that everyone in the household can have something they like. }\end{array}$ & 3.13 & 1.195 \\
\hline $\begin{array}{l}\text { Planning habits - I make shopping lists and only buy food items that } \\
\text { are on the list. }\end{array}$ & 2.92 & 1.200 \\
\hline Reusing food - In my household, we tend to reuse leftovers. & 3.29 & 1.133 \\
\hline $\begin{array}{l}\text { Food storage - I store food items in the appropriate manner to expand } \\
\text { their shelf life. }\end{array}$ & 4.26 & .837 \\
\hline Monthly average amount of food wasted & 1.44 & .497 \\
\hline
\end{tabular}

The correlations between the variables included in the study are shown in Annex no. 1 below.

\subsection{Predictors of intention to avoid food waste}

A hierarchical multiple regression analysis was performed in order to test TPB and determine whether personal attitudes, financial attitudes, perceived health risk, perceived behavioural control, subjective norms, personal norms, and good provider identity are significant predictors of intention to avoid food waste. The socio-demographic variables were not included in the model since the correlations table showed no significant associations between these variables and the intention to avoid food waste. The results of the analysis are presented in table no. 4.

Table no. 4. Hierarchical multiple regression of intention to reduce food waste

\begin{tabular}{|l|c|}
\hline Predictor & $\boldsymbol{\beta}$ \\
\hline Personal attitudes & $.399^{* *}$ \\
\hline Financial attitudes & $.122^{*}$ \\
\hline Perceived health risk & .038 \\
\hline Perceived behavioural control & $-.140^{*}$ \\
\hline Subjective norms & .071 \\
\hline Personal norms & $.191^{* *}$ \\
\hline Good provider identity & $-.192^{* *}$ \\
\hline $\mathbf{R}^{\mathbf{2}}$ & .432 \\
\hline Adjusted $\mathbf{R}^{\mathbf{2}}$ & .411 \\
\hline F & $20.242^{* *}$ \\
\hline
\end{tabular}

Notes: $* * \mathrm{p}<.01, * \mathrm{p}<.05$. 
The overall model accounted for $43.2 \%$ of the total variation in intention to avoid food waste and was statistically significant $(\mathrm{F}=20.2442 ; \mathrm{p}<.01)$. The strongest predictor of intention to avoid food waste were personal attitudes $(\beta=.399 ; \mathrm{p}<.01)$, followed by good provider identity $(\beta=-.192 ; \mathrm{p}<.01)$ and personal norms $(\beta=.191 ; \mathrm{p}<.01)$. Personal attitudes, financial attitudes and personal norms were positive predictors of intention to avoid food waste, while good provider identity and perceived behavioural control were negative predictors. Subjective norms and perceived health risk did not prove to be significant predictors of intention to avoid food waste. Overall hypothesis 1 was partially confirmed, since most of the variables introduced in the model were significant predictors of food waste.

\subsection{Impact of workaholism on the predictors of intention to avoid food waste}

A series of hierarchical multiple regression analyses were performed in order to determine whether workaholism (as a score and as individual items) significantly influence the predictors of intention to avoid food waste (see table no. 5). Since the correlations table revealed a number of significant associations between the socio-demographic characteristics and the predictors of intention to avoid food waste, the variables related to age, gender, household size, education, and household income were controlled for in the regression analysis by being entered at step 1 . At step 2, the variables used to measure workaholism were introduced to see whether they have a significant influence on each of the predictors of intention to avoid food waste.

Table no. 5. Hierarchical multiple regression of predictors of intention to reduce FW

\begin{tabular}{|c|c|c|c|c|c|c|c|}
\hline & $\begin{array}{l}\text { Personal } \\
\text { attitudes }\end{array}$ & $\begin{array}{l}\text { Financial } \\
\text { attitudes }\end{array}$ & $\begin{array}{l}\text { Perceived } \\
\text { behavioural } \\
\text { control }\end{array}$ & $\begin{array}{l}\text { Subjective } \\
\text { norms }\end{array}$ & $\begin{array}{l}\text { Personal } \\
\text { norms }\end{array}$ & $\begin{array}{l}\text { Good } \\
\text { provider } \\
\text { identity }\end{array}$ & $\begin{array}{l}\text { Perceived } \\
\text { health } \\
\text { risk }\end{array}$ \\
\hline \multicolumn{8}{|c|}{ Predictors step 1} \\
\hline Age & .011 & .086 & .003 & -.016 & .041 & .012 & -.036 \\
\hline Gender & $.452 * *$ & .177 & .022 & .109 & $.380 *$ & .122 & -.117 \\
\hline Education & .078 & -.119 & -.075 & -.072 & -.005 & .006 & -.144 \\
\hline $\begin{array}{l}\text { Household } \\
\text { size }\end{array}$ & .095 & -.025 & .023 & .036 & $.160^{*}$ & .123 & -.083 \\
\hline $\begin{array}{l}\text { Household } \\
\text { income }\end{array}$ & .088 & .074 & -.017 & -.154 & -.095 & -.017 & -.004 \\
\hline $\mathbf{R}^{2}$ & .064 & .019 & .005 & .034 & .069 & .019 & .023 \\
\hline Adjusted R ${ }^{2}$ & .039 & -.007 & -.021 & .009 & .045 & -.007 & -.002 \\
\hline $\mathbf{F}$ & $2.582 *$ & .723 & .199 & 1.337 & 2.803 & .745 & .904 \\
\hline \multicolumn{8}{|c|}{ Predictors step 2} \\
\hline Age & .031 & .098 & -.005 & .088 & .001 & -.042 & -.021 \\
\hline Gender & $.406 *$ & .135 & .003 & .137 & $.368 *$ & .130 & -.155 \\
\hline Education & .050 & -.119 & -.073 & -.055 & -.042 & .008 & -.185 \\
\hline $\begin{array}{l}\text { Household } \\
\text { size }\end{array}$ & .119 & -.014 & .049 & .046 & $.153^{*}$ & .136 & -.078 \\
\hline $\begin{array}{l}\text { Household } \\
\text { income }\end{array}$ & .106 & .090 & -.002 & -.134 & -.087 & -.023 & .006 \\
\hline Salience & -.132 & -.110 & .000 & .037 & -.002 & .021 & -.155 \\
\hline Tolerance & .016 & .014 & .029 & .020 & .144 & .155 & .095 \\
\hline $\begin{array}{l}\text { Mood } \\
\text { modification }\end{array}$ & .062 & .035 & .056 & -.118 & -.105 & -.064 & -.048 \\
\hline Relapse & -.096 & .040 & .032 & .121 & .131 & -.063 & -.069 \\
\hline
\end{tabular}




\begin{tabular}{|l|c|c|l|l|l|l|l|}
\hline & $\begin{array}{l}\text { Personal } \\
\text { attitudes }\end{array}$ & $\begin{array}{l}\text { Financial } \\
\text { attitudes }\end{array}$ & $\begin{array}{l}\text { Perceived } \\
\text { behavioural } \\
\text { control }\end{array}$ & $\begin{array}{l}\text { Subjective } \\
\text { norms }\end{array}$ & $\begin{array}{l}\text { Personal } \\
\text { norms }\end{array}$ & $\begin{array}{l}\text { Good } \\
\text { provider } \\
\text { identity }\end{array}$ & $\begin{array}{l}\text { Perceived } \\
\text { health } \\
\text { risk }\end{array}$ \\
\hline Withdrawal & .019 & -.102 & -.048 & .038 & .102 & .021 & .082 \\
\hline Conflict & .116 & -.007 & -.041 & -.091 & .014 & -.023 & .118 \\
\hline Problems & -.048 & .013 & .131 & $.300^{* *}$ & .064 & .073 & -.087 \\
\hline Workaholism & .024 & -.087 & .127 & .088 & .250 & -.141 & -.068 \\
\hline $\mathbf{R}^{\mathbf{2}}$ & .089 & .041 & .026 & .129 & .124 & .061 & .059 \\
\hline Adjusted R & .024 & -.028 & -.044 & .066 & .061 & -.007 & -.009 \\
\hline F & 1.358 & .861 & .374 & $2.051^{*}$ & 1.957 & .898 & .875 \\
\hline delta R & .025 & .022 & .021 & .095 & .054 & .041 & .036 \\
\hline delta F & .620 & .515 & .486 & $2.445^{*}$ & 1.399 & .994 & .860 \\
\hline
\end{tabular}

Notes: $* * \mathrm{p}<.01, * \mathrm{p}<.05$.

In the case of personal attitudes, in step 1, only gender proved to be a significant predictor $(\beta=.452 ; \mathrm{p}<.01)$ and the addition of the variables related to workaholism in step 2 did not improve the model. Both models performed very poorly since they accounted for less than $1 \%$ of the variance in personal attitudes. As a result, it can be concluded that workaholism does not have a significant impact on personal attitudes related to food waste. In the case of financial attitudes, perceived behavioural control, good provider identity and perceived health risk none of the predictors included in the model showed significant results, which means that neither the socio-demographic variables nor the workaholism variables were good predictors of financial attitudes related to food waste, perceived behavioural control related to food waste, good provider identity or perceived health risk associated with the consumption of recently expired food. In the case of subjective norms, the sociodemographic variables did not show a significant impact, but the variable related to workaholism 'problems' proved to be a good predictor $(\beta=.300 ; p<.01)$. However, the model obtained in step 2 accounted for only $12.9 \%$ of the variance in subjective norms $(\mathrm{F}=2.051$; $\mathrm{p}<.01)$. Thus, it can be concluded that the health problems caused by workaholism act as a somewhat good predictor of subjective norms related to food waste. In the case of personal norms, in step 1 , gender $(\beta=.380 ; p<.05)$ and household size $(\beta=.160 ; p<.05)$ proved to be significant predictors and the overall model accounted for $6.9 \%$ of the total variance in personal norms. However, the addition of the variables related to workaholism in step 2 did not improve the fit of the model and showed no significant impact, which leads us to the conclusion that workaholism does not have a significant impact on personal norms related to food waste. Thus, hypothesis 2 was only partially confirmed, since only one item from the workaholism scale (i.e., 'problems') acted as a significant predictor of subjective norms related to food waste.

\subsection{Impact of workaholism on food waste behaviours}

In order to test the third hypothesis, we performed a series of hierarchical multiple regressions for each behaviour related to food waste, the predictors being intention to avoid food waste and workaholism. In step 1 we entered the socio-demographic variables which needed to be controlled for since there existed a couple of significant correlations with the independent variable (i.e., amount of food wasted). In step 2 we entered intention to avoid food waste and in step 3 we entered the variables related to workaholism to gauge the impact that workaholism has on food waste behaviours (see table no. 6). 
In the case of planning habits, step 1 revealed that age $(\beta=.155 ; \mathrm{p}<.05$ and household income $(\beta=.170 ; p<.05)$ were significant predictors and the overall model accounted for $5 \%$ of the total variance in planning habits. The addition of intention to food waste had a significant positive effect on the overall fit of the model since in step 2 the predictors accounted for $14.5 \%$ of the total variance in planning habits $(\mathrm{F}=5.304 ; \mathrm{p}<.01)$. The introduction of the variables related to workaholism in step 3 improved the $\mathrm{R}^{2}$ obtained (17.6\%), but none of the variables were significant predictors and delta $\mathrm{F}$ was also not statically significant. Thus, it can be concluded that workaholism does not have a significant impact on planning habits related to food shopping.

Table no. 6. Hierarchical multiple regression of food waste behaviours

\begin{tabular}{|c|c|c|c|c|}
\hline & $\begin{array}{c}\text { Planning } \\
\text { habits }\end{array}$ & $\begin{array}{c}\text { Reusing } \\
\text { food }\end{array}$ & $\begin{array}{c}\text { Food } \\
\text { Storage } \\
\end{array}$ & $\begin{array}{c}\text { Amount of food } \\
\text { wasted }\end{array}$ \\
\hline \multicolumn{5}{|l|}{ Predictors step 1} \\
\hline Age & $.155 *$ & -.081 & -.069 & -.085 \\
\hline Gender & .153 & -.075 & .299 & .079 \\
\hline Education & -.144 & .007 & -.133 & -.025 \\
\hline Household size & -.093 & .002 & -.014 & -.018 \\
\hline Household income & $.170^{*}$ & $.194 *$ & .062 & -.045 \\
\hline $\mathbf{R}^{2}$ & .050 & .042 & .030 & .051 \\
\hline Adjusted $\mathbf{R}^{2}$ & .025 & .016 & .004 & .026 \\
\hline $\mathbf{F}$ & 1.991 & 1.647 & 1.148 & 2.011 \\
\hline \multicolumn{5}{|l|}{ Predictors step 2} \\
\hline Age & $.175^{*}$ & -.059 & -.041 & -.092 \\
\hline Gender & .105 & -.127 & .233 & .095 \\
\hline Education & -.145 & .007 & -.133 & -.025 \\
\hline Household size & -.106 & -.011 & -.031 & -.013 \\
\hline Household income & .139 & $.160^{*}$ & .018 & -.034 \\
\hline Intention to avoid FW & $.311 * *$ & $.337 * *$ & $.435 * *$ & $-.106 * *$ \\
\hline $\mathbf{R}^{2}$ & .145 & .153 & .215 & .095 \\
\hline Adjusted $\mathbf{R}^{2}$ & .118 & .126 & .190 & .066 \\
\hline F & $5.304 * *$ & $5.647 * *$ & $8.551 * *$ & $3.280 * *$ \\
\hline delta $R^{2}$ & .095 & .111 & .186 & .044 \\
\hline delta F & $20.821 * *$ & $24.611 * *$ & $44.246 * *$ & $9.192 * *$ \\
\hline \multicolumn{5}{|l|}{ Predictors step 3} \\
\hline Age & .151 & -.036 & -.066 & -.093 \\
\hline Gender & .083 & -.098 & .205 & .119 \\
\hline Education & -.137 & -.019 & -.114 & -.020 \\
\hline Household size & -.087 & .035 & -.036 & -.001 \\
\hline Household income & .145 & $.174 *$ & .015 & -.030 \\
\hline Intention to avoid FW & $.324 * *$ & $.337 * *$ & $.443 * *$ & $-.107 * *$ \\
\hline Salience & .124 & -.082 & .131 & -.034 \\
\hline Tolerance & -.005 & .080 & -.065 & .030 \\
\hline Mood modification & .089 & -.009 & .061 & -.017 \\
\hline Relapse & .032 & $-.203^{*}$ & .034 & -.014 \\
\hline Withdrawal & -.076 & $.221 *$ & -.143 & .048 \\
\hline Conflict & .027 & -.032 & $.223^{*}$ & $-.178 * *$ \\
\hline Problems & .083 & $.171^{*}$ & -.090 & $.139 * *$ \\
\hline Workaholism & .170 & .089 & .305 & -.187 \\
\hline $\mathbf{R}^{2}$ & .176 & .228 & .264 & .206 \\
\hline
\end{tabular}




\begin{tabular}{|l|c|c|c|c|}
\hline & $\begin{array}{c}\text { Planning } \\
\text { habits }\end{array}$ & $\begin{array}{c}\text { Reusing } \\
\text { food }\end{array}$ & $\begin{array}{c}\text { Food } \\
\text { Storage }\end{array}$ & $\begin{array}{c}\text { Amount of food } \\
\text { wasted }\end{array}$ \\
\hline Adjusted R $\mathbf{2}^{\mathbf{2}}$ & .111 & .167 & .206 & .144 \\
\hline F & $2.727 * *$ & $3.772 * *$ & $4.582^{* *}$ & $3.322^{* *}$ \\
\hline delta R & .030 & .074 & .049 & .111 \\
\hline delta F & .824 & $2.158 *$ & 1.475 & $3.128 * *$ \\
\hline
\end{tabular}

Notes: $* \mathrm{p}<.05, * * \mathrm{p}<.01$.

In the case of reusing food, step 1 showed that only household income $(\beta=.194 ; p<.05)$ was a significant predictor and the overall model accounted for only $4.2 \%$ of the total variance in reusing food. The addition of intention to avoid food waste in step 2 improved the model significantly, the total variance explained being $15.3 \%$. Furthermore, step 3 revealed that problems is also a significant predictor of reusing food and the resulting $\mathrm{R}^{2}$ was $17.6 \%$ $(\mathrm{F}=3.772 ; \mathrm{p}<.01)$. Moreover, the change in $\mathrm{F}$ was statistically significant, which means that workaholism (i.e., problems) has a significant impact on reusing food.

In the case of food storage, none of the socio-demographic variables were significant predictors. However, in step 2 , intention to avoid food waste $(\beta=.435 ; \mathrm{p}<.01)$ proved to be a significant predictor and the overall model accounted for $21.5 \%$ of the total variance in food storage $(\mathrm{F}=8.551 ; \mathrm{p}<.01)$. The addition of the variables related to workaholism in step 3 did not lead to a significant improvement of the model but did show that conflict $(\beta=.223 ; \mathrm{p}<.05)$ is a significant predictor of food storage.

In the case of the amount of food wasted, there were no significant predictors among the socio-demographic variables, but intention to avoid food waste $(\beta=-.106 ; \mathrm{p}<.01)$ was a significant predictor. The overall model in step 2 accounted for $9.5 \%$ of the total variance in amount of food wasted $(\mathrm{F}=3.280 ; \mathrm{p}<.01)$. In addition, based on the analysis from step 3 it was found that conflict $(\beta=-.178 ; \mathrm{p}<.01)$ and problems $(\beta=.139 ; \mathrm{p}<.01)$ were also significant predictors of the amount of food wasted. The overall model from step 3 accounted for $20.6 \%$ of the total variation in amount of food wasted $(\mathrm{F}=3.322 ; \mathrm{p}<.01)$. Moreover, the addition of the variables related to workaholism significantly improved the model which led to the conclusion that workaholism (i.e., conflict and problems) has a significant impact on the amount of food wasted.

To further explore the impact of conflict and problems on the amount of food wasted at the consumer level we focused on the exploration of the behaviour of three main groups of workaholics: non-workaholics (i.e., those with values for conflict and problems below 3), functional workaholics (i.e., those with values above 3 for conflict, but values below 3 for problems) and problematic workaholics (i.e., those with values above 3 for both conflict and problems). The comparison of the means for amount of food wasted done using one-way ANOVA with LSD post-hoc contrasts showed that there is a significant difference between the mean of the amount of food wasted by functional workaholics $(\mathrm{M}=1.30 ; \mathrm{SD}=.470)$ and that of problematic workaholics $(\mathrm{M}=1.61 ; \mathrm{SD}=.495)$. The results of the analysis are shown in table no. 7 . 
Table no. 7. One-way ANOVA for comparison between different types of workaholics and their food waste

\begin{tabular}{|l|c|c|c|c|}
\hline Type & M & SD & $\begin{array}{c}\text { Mean difference (compared } \\
\text { to problematic workaholics) }\end{array}$ & F \\
\hline Non-workaholics & 1.45 & .506 & -.161 & \multirow{2}{*}{2.504} \\
\hline Functional workaholics & 1.30 & .470 & $-.313^{*}$ & \\
\hline Problematic workaholics & 1.61 & .495 & 0 & \\
\hline
\end{tabular}

Notes: $* \mathrm{p}<.05$.

A summary of the main findings is shown in table no. 8 .

Table no. 8. Summary of findings

\begin{tabular}{|c|l|l|}
\hline \multirow{4}{*}{$\begin{array}{c}\text { Hypothesis } \\
1\end{array}$} & Personal attitudes $\rightarrow$ Intention to avoid food waste & Confirmed \\
\cline { 2 - 3 } & Financial attitudes $\rightarrow$ Intention to avoid food waste & Confirmed \\
\cline { 2 - 3 } & Perceived health risk $\rightarrow$ Intention to avoid food waste & Rejected \\
\cline { 2 - 3 } & $\begin{array}{l}\text { Perceived behavioral control } \rightarrow \text { Intention to avoid food } \\
\text { waste }\end{array}$ & Confirmed \\
\cline { 2 - 3 } & Subjective norms $\rightarrow$ Intention to avoid food waste & Rejected \\
\cline { 2 - 3 } & Personal norms $\rightarrow$ Intention to avoid food waste & Confirmed \\
\cline { 2 - 3 } Hypothesis & Good provider identity $\rightarrow$ Intention to avoid food waste & Confirmed \\
\hline \multirow{5}{*}{2} & Workaholism $\rightarrow$ Personal attitudes & Rejected \\
\cline { 2 - 3 } & Workaholism $\rightarrow$ Financial attitudes & Rejected \\
\cline { 2 - 3 } & Workaholism $\rightarrow$ Perceived health risk & Rejected \\
\cline { 2 - 3 } & Workaholism $\rightarrow$ Perceived behavioral control & Rejected \\
\cline { 2 - 3 } & Workaholism (problems) $\rightarrow$ Subjective norms & Confirmed \\
\cline { 2 - 3 } & Workaholism $\rightarrow$ Personal norms & Rejected \\
\cline { 2 - 3 } Hypothesis & Workaholism $\rightarrow$ Good provider identity & Rejected \\
\hline \multirow{5}{*}{3} & Intention to avoid food waste $\rightarrow$ Amount of food wasted & Confirmed \\
\cline { 2 - 3 } & $\begin{array}{l}\text { Workaholism (conflict, problems) } \rightarrow \text { Amount of food } \\
\text { wasted }\end{array}$ & Confirmed \\
\cline { 2 - 3 } & Intention to avoid food waste $\rightarrow$ Planning habits & Confirmed \\
\cline { 2 - 3 } & Workaholism $\rightarrow$ Planning habits & Rejected \\
\cline { 2 - 3 } & Intention to avoid food waste $\rightarrow$ Food storage & Confirmed \\
\cline { 2 - 3 } & Workaholism (conflict) $\rightarrow$ Food storage & Confirmed \\
\cline { 2 - 3 } & Intention to avoid food waste $\rightarrow$ Reusing food & \\
\cline { 2 - 3 } & $\begin{array}{l}\text { Workaholism (relapse, withdrawal, problems) } \rightarrow \text { Reusing } \\
\text { food }\end{array}$ & Confirmed \\
\hline
\end{tabular}

Workaholism is a complex phenomenon which has sparked the interest of both scholars and managers since it has a significant impact on individuals, on organizations and the whole society. Until a few decades ago, workaholism was regarded as a positive attribute which was extremely desirable since it was associated with a swift career advancement and high work productivity. However, more recent studies have shown that workaholism also has a variety of negative consequences including poor physiological and psychological health, strained family relations and poor work productivity. The present study started from the premise that workaholism is triggered by low self-esteem (Porter, 2004) and that a high level of workaholism leads to business success (Hewitt and Luce, 2006) which determines 
financial stability (Harpaz and Snir, 2003). Since workaholics have a low self-esteem, they are prone to engage in self-providing behavioural with external rewards (Porter, 2004) which can include buying discretionary amount of foods that could lead to food waste. Thus, in line with the assumptions made by previous studies (Maccheroni, et al., 2014; Ilyn, 2015), we assumed that there will be a direct positive relation of influence between workaholism and food waste at the consumer level. However, the results showed that there was no clear correlation between workaholism as an overall score and the level of food waste at the consumer level. This could be explained by the fact that workaholism had no significant impact on the predictors of the intention to avoid food waste and also by the fact that we employed a unidimensional scale for workaholism that viewed workaholism as a psychological issue (i.e., addiction) instead of other scales that also account for the positive psychological aspects of workaholism.

\section{Conclusions}

The main contribution of the present study consists in the proving that it is fruitful to explore the connections between workaholism and consumer food waste both from a theoretical but also a managerial point of view. The results obtained showed not only that the traditional model based on the theory of planned behaviour is applicable to the study of consumer food waste in Romania, but also that the model can be extended with the addition of workaholism as a direct predictor of several food waste behaviours. In particular, it is extremely important to further investigate the impact of conflict and problems on the amount of food wasted at the consumer level since the present findings indicate that based on the configurations of the scale to which respondents experience conflict and problems we obtain different levels of food waste. The fact that functional workaholics produce less food waste than problematic workaholics can be explained by their human and conjectural profile as follows: a) Functional workaholics, similar to enthusiastic workaholics, are thoroughly engaged in their work and fulfilled by their work results to a larger degree than problematic workaholics; b) Functional workaholics are more positively invested in their work in comparison to problematic workaholics; c) Functional workaholics benefit from a higher level of support from their significant others in their attempts to reduce household food waste in comparison to problematic workaholics. These aspects have an impact both in an individual manner, but also in a combined manner on the ability to plan behaviour related to food waste. From a managerial point of view, knowing about these typologies and causalities and, implicitly, encouraging functional workaholism, can lead not only to better organizational results, but also to a higher sustainability/efficiency of the actions aimed at reducing food waste.

The present study suffers from several limitations, which must be taken into consideration when analysing the results. First, the study relied on convenience sampling and the resulting sample was biased since it included more females than males and more people with university education than people with high school or lower levels of education. Thus, the sample is not exactly representative of the population of Romanian employees and further studies could improve the results by employing probabilistic sampling techniques and ensuring that all socio-demographic categories are fairly represented. Second, the study employed a selfreported survey and relied on the estimations of the respondents regarding both the number of hours worked and the amount of food wasted in their households. Past studies have shown that individuals tend to underestimate the amount of food wasted (Elimelech, Ert and Ayalon, 2019) and it is safe to assume that a similar bias is possible in the case of the estimation of 
the number of hours worked. As a result, future studies should seek to employ a combination of data collection methods that allows for the direct observation of the actual behaviour of the respondents in order to strengthen the reliability of the data. Third, the study relied on a unidimensional scale for workaholism which did not allow for the classification of the respondents into different types of workaholics as usually done in most recent studies. Since the results suggest that different facets of workaholism have different impacts on food waste, it would be advisable for future studies to employ more in-depth scales which also allow the distinction between different type of workaholic behaviour. Finally, the scope of the research framework was limited to only a selection of predictors of food waste and of food waste behaviours and further studies should particularly explore the connection between workaholism and take away food or eating out since these are two significant predictors of food waste at the consumer level.

\section{References}

Andreassen, C.S., 2014. Workaholism: An overview and current status of the research. Journal of Behavioral Addictions, 3(1), pp.1-11.

Andreassen, C.S., 2013. Work addiction. In: Miller, P. (Ed.). Principles of Addiction: Comprehensive addictive Behaviors and Disorders. San Diego: Elsevier.

Andreassen, C. S., Griffiths, M. D., Hetland, J. and Pallesen, S., 2012. Development of a work addiction scale. Scandinavian Journal of Psychology, 53(3), pp.265-272.

Andreassen, C., Ursin, H. and Eriksen, H., 2007. The relationship between strong motivation to work, "workaholism", and health. Psychology \& Health, 22(5), pp.615-629.

Bonebright, C.A., Clay, D.L. and Ankenmann, R.D., 2000. The relationship of workaholism with work-life conflict, life satisfaction, and purpose in life. Journal of Counseling Psychology, 47(4), pp.469-477.

Brown, R.I.F., 1993. Some contributions of the study of gambling to the study of other addictions. In: Eadington, W.R. and Cornelius, J.A. (Eds.). Gambling behavior and problem gambling. Reno: University of Nevada Press. pp.241-272.

Castillo, J.A. and Gómez M.C., 2012. Excessive work or addiction to work: workaholism in a Colombian company. A pilot study trough application of DUWAS test. Revista Ciencias de la Salud, 10(3), pp.307-322.

Chamberlin, C.M. and Zhang, N., 2009. Workaholism, health, and self-acceptance. Journal of Counseling \& Development, 87(2), pp.159-169.

Clark, L.A., 1993. Schedule for Nonadaptive and Adaptive Personality (SNAP): Manual for Administration, Scoring, and Interpretation. Minneapolis: University of Minnesota Press.

Clark, M.A., Lelchook, A.M. and Taylor, M.L., 2010. Beyond the Big Five: How narcissism, perfectionism, and dispositional affect relate to workaholism. Personality \& Individual Differences, 48(7), pp.786-791.

Elimelech, E., Ert. E. and Ayalon, O., 2019. Bridging the gap between self-assessments and measured household food waste: A hybrid valuation approach. Waste Management, 95(July), pp.259-270.

Graham-Rowe, E., Jessop, D.C. and Sparks, P., 2015. Predicting household food waste reduction using an extended theory of planned behaviour. Resources, Conservation and Recycling, 101(August), pp.194-202. 
Griffiths, M.D., 2005. A components model of addiction within a biopsychological framework. Journal of Substance Use, 10(4), pp.191-197.

Griffiths, M.D., 2011. Workaholism: A 21st century addiction. The Psychologist: Bulletin of the British Psychological Society, 24(October), pp.740-744.

Harpaz, I. and Snir, R., 2003. Workaholism: Its definition and nature. Human Relations, 56(3), pp.291-319.

Hewett, S. and Luce, C., 2006. Extreme jobs: The dangerous allure of the 70-hour workweek. Harvard Business Review, 84(12), pp.49-59.

Ilyin, A.N., 2015. The culture of consumption as a factor la labor management. Management Issues, 36(5), pp.1-11.

Ishiyama, F. and Kitayama, A., 1994. Overwork and career-centered self-validation among the Japanese: Psychosocial issues and counselling implications. International Journal for the Advancement of Counselling, 17(3), pp.167-182.

Kubota, K., Shimazu, A., Kawakami, N., Takahashi, M., Nakata, A. \& Schaufeli, W.B., 2010. Association between workaholism and sleep problems among hospital nurses. Industrial Health, 48(3), pp.864-871.

Maccheroni, F., Marinacci, M. and Rustichini, A., 2014. Pride and diversity in social economies. American Economic Journal: Microeconomics, 6(4), pp.237-271.

Machlowitz, M., 1980. Workaholics: Living with them, working with them. Reading: Addison-Wesley.

Mak, T.M. W., Yu, I.K. M. and Tsang, D.C.W., 2020. Theory of planned behavior on food waste recycling. In: Bhaskar, T., Pandey, A., Rene, R.E. \& Tsang, D.C.W. (Eds.). Waste Biorefinery. Amsterdam: Elsevier. pp.221-239.

Mondejar-Jimenez, J.-A., Ferrari, G., Secondi, L. and Principato, L., 2016. From the table to waste: An exploratory study on behaviour towards food waste of Spanish and Italian youths. Journal of Cleaner Production, 138(2), pp.8-18.

Mosier, S.K., 1983. Workaholics: An analysis of their stress, success, and priorities. Master's thesis. University of Texas.

Mudrack, P.E. and Naughton, T.J., 2001. The assessment of workaholism as behavioral tendencies: Scale development and preliminary empirical testing. International Journal of Stress Management, 8(1), pp.93-111.

Ng, T.W.H., Sorensen, K.L. and Feldman, D.C., 2007. Dimensions, antecedents, and consequences of workaholism: A conceptual integration and extension. Journal of Organizational Behavior, 28(1), pp.111-136.

Oates, W., 1971. Confessions of a workaholic: The facts about work addiction. New York: World.

Patel, A.S., Bowler, M.C., Bowler, J.L. and Methe, S.A., 2012. A meta-analysis of workaholism. International Journal of Business and Management, 7(11), pp.2-7.

Peiperl, M. and Jones, B., 2001. Workaholics and overworkers: Productivity or pathology? Group \& Organization Management, 26(3), pp.369-393.

Porter, G., 1996. Organizational impact of workaholism: Suggestions for researching the negative outcomes of excessive work. Journal of Occupational Health Psychology, 1(1), pp.70-84. 
Porter, G., 2004. Work, work ethic, work excess. Journal of Organizational Change Management, 17(5), pp.424-439.

Robinson, B.E., 1996. Concurrent validity of the work addiction risk test as a measure of workaholism. Psychological Reports, 79(3), pp.1313-1314.

Robinson, B. E., 2013. Chained to the desk: A guidebook for workaholics, their partners and children, and the clinicians who treat them. New York: New York University Press.

Russell, S.V., Young, W.C., Unsworth, K.L. and Robinson, C., 2017. Bringing habits and emotions into food waste behaviour. Resources, Conservation and Recycling, 125(October), pp.107-114.

Schaufeli, W. and Taris T., 2004. Technical information. Dutch Work Addiction Scale (DUWAS). [pdf] Available at: <www.wilmarschaufeli.nl/publications/Schaufeli/Test \%20Manuals/Scoring_DUWAS.pdf> [Accessed 17 June 2020].

Schaufeli, W. B., Shimazu, A. and Taris, T.W., 2009. Being driven to work excessively hard. The evaluation of a two-factor measure of workaholism in the Netherlands and Japan. Cross-Cultural Research, 43(4), pp.320-348.

Schaufeli, W.B., Taris, T.W. and van Rhenen, W., 2008. Workaholism, burnout, and work engagement: Three of a kind or three different kinds of employee well-being? Applied Psychology: An International Review, 57(2), pp.173-203.

Scott, K.S., Moore, K.S. and Miceli, M.P., 1997. An exploration of the meaning and consequences of workaholism. Human Relations, 50(3), pp.287-314.

Snir, R. and Harpaz, I., 2012. Beyond workaholism: Towards a general model of heavy work investment. Human Resource Management Review, 22(3), pp.232-243.

Soorani, F. and Ahmadvand, M., 2019. Determinants of consumers' food management behavior: Applying and extending the theory of planned behavior. Waste Management, 98(October), pp.151-159.

Spence, J.T. and Robbins, A.S., 1992. Workaholism: definition, measurement, and preliminary results. Journal of Personality Assessment, 58(1), pp.160-178.

Sussman, S., 2012. Workaholism: A review. Journal of Addiction Research and Theory, 6(1), pp.1-10.

Taris, T.W., Schaufeli, W.B. and Shimazu, A., 2010. The push and pull of work: The difference between workaholism and work engagement. In: Bakker, A. B. and Leiter, M. P. (Eds.). Work Engagement. A Handbook of Essential Theory and Research. Hove: Pscyhological Press. pp.39-53.

Taris, T.W., Schaufeli, W.B. and Verhoeven, L.C., 2005. Workaholism in the Netherlands: Measurement and implications for job strain and work-nonwork conflict. Applied Psychology: An International Review, 54(1), pp.37-60.

Taris, T.W., van Beek, I. and Schaufeli, W.B., 2012. Demographic and occupational correlates of workaholism. Psychological Reports, 110(2), pp.547-554.

van Beek, I., Taris, T.W. and Schaufeli, W.B., 2011. Workaholic and work engaged employees: Dead ringers or worlds apart? Journal of Occupational Health Psychology, 16(4), pp.468-482.

Visschers, V.H.M., Wickli, N. and Siegrist, M., 2016. Sorting out food waste behaviours: A survey on the motivators and barriers of self-reported amounts of food waste in households. Journal of Environmental Psychology, 45(March), pp.66-78. 


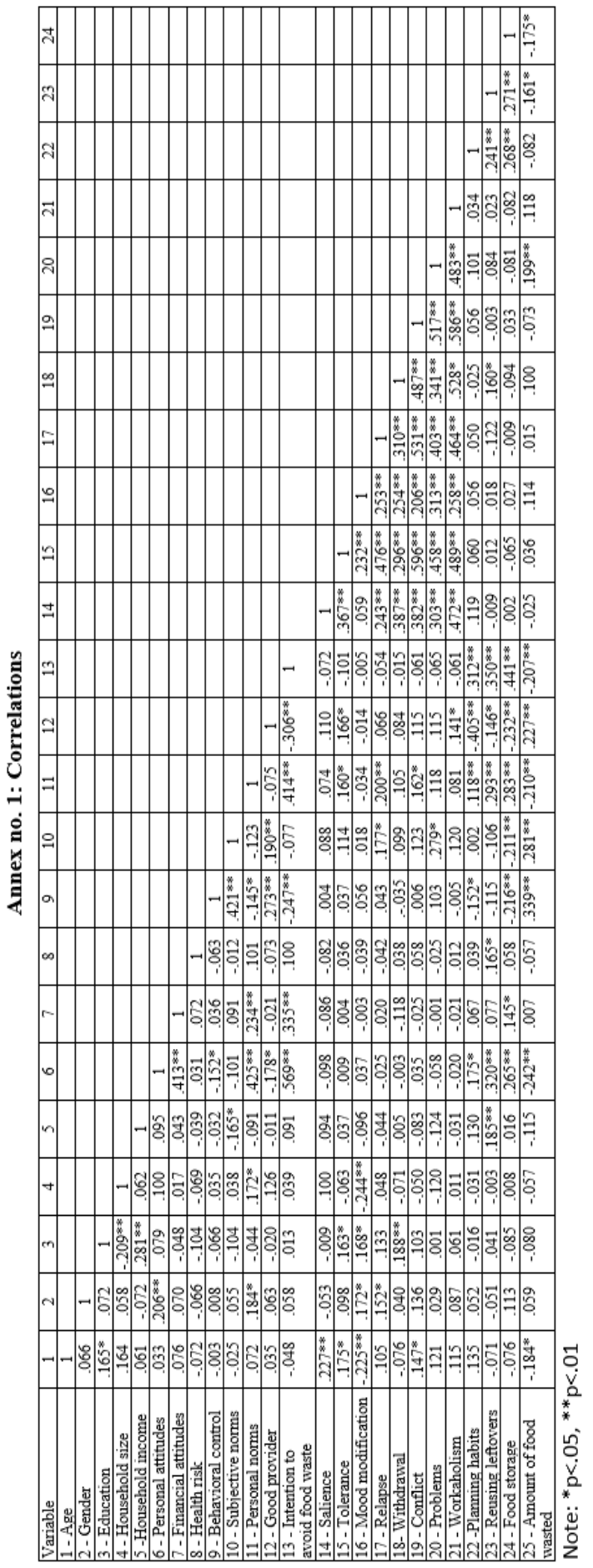

